\title{
Epididymal proteins mimic the androgenic effect on zona pellucida recognition by immature hamster spermatozoa
}

\author{
Patricia S. Cuasnicú, Fernanda González Echeverría, Alejandra Piazza, \\ Lucrecia Piñeiro and J. A. Blaquier
}

Instituto de Biología y Medicina Experimental, Obligado 2490, 1428 Buenos Aires, Argentina

\begin{abstract}
Summary. The increase in zona pellucida binding caused by the exposure of cultured proximal corpus epididymidis to $2 \mu \mathrm{M}-5 \alpha$-DHT $(0.87$ and 4.29 spermatozoa/egg for control and $5 \alpha$-DHT group respectively) was lost when $20 \mu \mathrm{M}$-cycloheximide was also added to the medium $(0.72$ spermatozoa/egg $)$. These results were interpreted as meaning that de-novo protein synthesis was required to obtain the effect of androgens. When a fraction enriched in epididymal glycoproteins EP2-EP6 $(18 \%$ total protein in epididymal cytosol and $30 \%$ in enriched fraction) and depleted of androgens ( $<120 \mathrm{pg}$ testosterone $+\mathrm{DHT} / \mathrm{ml}$ ) was added to the cultured epididymal tubules, the zona pellucida-binding ability of the contained spermatozoa increased from 0.55 in controls to 2.73 spermatozoa/egg in the extract-treated group $(P<0.02)$. When the enriched fraction was prepared from epididymides of 30 -day castrates, the stimulatory effect was lost ( 1.04 spermatozoa/egg). We suggest that proteins synthesized in the epididymis are required to obtain the effect of androgens and that the glycoproteins EP2-EP6 may be involved.
\end{abstract}

\section{Introduction}

We have described an organ culture technique which allowed the maintenance of hamster epididymal tubules and contained spermatozoa in a viable condition and able to respond to androgenic stimulation (Cuasnicú, González Echeverria, Piazza \& Blaquier, 1984). The addition of the androgen $5 \alpha$-dihydrotestosterone $(5 \alpha-\mathrm{DHT})$ to the culture medium increased the synthesis of glycoproteins EP1-EP6 (González Echeverría, Cuasnicú \& Blaquier, 1982) and their attachment to spermatozoa, and this sperm population had a greater ability to bind to zonae pellucidae than did unstimulated control spermatozoa (Cuasnicú et al., 1984). The evidence was interpreted as supporting the hypothesis that a receptor for the zona pellucida is assembled, or activated, on the sperm surface during maturation with the intervention of epididymal factors. This, in turn, is in agreement with the postulate that the development of oocyte recognition is one of the main determinants of the acquisition of the fertilizing ability that occurs during epididymal maturation (Saling, 1982; Fournier-Delpech, Courtens, Pisselet, Delaleu \& Courot, 1982).

In the present communication, we have investigated further the effects of androgen-induced proteins synthesized by the epididymis on sperm maturation. 


\section{Materials and Methods}

Adult male (8-12 weeks old) and immature female (5-7 weeks old) hamsters (Mesocricetus auratus) were maintained in $14 \mathrm{~h}$ light $/ 24 \mathrm{~h}$. Females were induced to superovulate by injection of $30 \mathrm{i} . \mathrm{u}$. PMSG followed by 40 i.u. hCG 48-72 h later. The oocytes were recovered from the oviducts $17 \mathrm{~h}$ after injection of hCG and used for the sperm binding assay. Oocytes were incubated for $2 \mathrm{~h}$ at $37^{\circ} \mathrm{C}$ in Brinster's (1965) medium BMOC and for $10 \mathrm{~min}$ in $0.1 \%$ hyaluronidase in Medium BMOC to remove cumulus cells.

The technique for organ culture of proximal corpus tubules (segment $b$ of Horan \& Bedford, 1972 ) and the spermatozoa-zona pellucida binding assay were as described previously (Cuasnicú $e t$ al., 1984).

To test the effect of androgens upon the cultured tubules and spermatozoa, $2 \mu \mathrm{M}-5 \alpha$-dihydrotestosterone was added to the medium during the 24 -h culture period. When desired, $20 \mu \mathrm{M}$-cycloheximide (Sigma Chemical Co., St Louis, MO, U.S.A.) was also added to the medium.

To study the possible direct effect of secreted epididymal proteins EP1 to EP6 (González Echeverría et al., 1982), a fraction enriched in androgen-dependent hamster epididymal glycoproteins was obtained as follows. Epididymal cytosol was prepared by homogenization of the tissue in 3 volumes $50 \mathrm{~mm}$-Tris pH 7.8 containing $0.25 \mathrm{M}$-sucrose, $1 \mathrm{mM}$-EDTA and $0.25 \mathrm{~mm}$-dithiothreitol, followed by centrifugation at $105000 \mathrm{~g}$ for $1 \mathrm{~h}$. The cytosol was chromatographed in a DEAE-Sephadex column (Garberi, Kohane, Cameo \& Blaquier, 1979) and the fraction eluted between 0.12 and $0.25 \mathrm{M}-\mathrm{NaCl}$ was collected, dialysed and freeze-dried. After analysis in $10 \%$ polyacrylamide gels, this fraction was found to be enriched in the androgen-induced glycoproteins identified as EP2-EP6. The composition of cytosol and enriched fraction, obtained by densitometry at $550 \mathrm{~nm}$, is shown in Table 1. Identical purification steps were followed with epididymal cytosol obtained from hamsters castrated 30 days earlier and the corresponding fraction (Table 1) was used as control. When used, these extracts were added to the medium to obtain a final concentration of $1 \mathrm{mg}$ protein $/ \mathrm{ml}$.

Table 1. Percentage protein composition of cytosol and enriched fractions obtained from epididymides from intact hamsters and hamsters castrated 30 days earlier

\begin{tabular}{lccc}
\hline & & \multicolumn{2}{c}{ Enriched fraction } \\
\cline { 3 - 4 } \multicolumn{1}{c}{ Fraction } & Cytosol & Intact animals & Castrated animals \\
\hline EP2-EP6 & 18 & 30 & 8 \\
EP2 + EP3 & 6 & 16 & 2 \\
Albumin & 8 & 10 & 14 \\
Other protein & 74 & 60 & 78 \\
\hline
\end{tabular}

Protein $(100 \mu \mathrm{g})$ from each fraction was analysed in $10 \%$ PAGE, stained with Coomassie Blue and, after destaining, scanned at $550 \mathrm{~nm}$.

Since the epididymis is known to contain a high concentration of endogenous androgen, samples of the enriched protein fractions were examined in a radioimmunoassay for testosterone and $5 \alpha$-dihydrotestosterone (courtesy of Dr Eduardo Charreau, Instituto de Biología y Medicina Experimental). The concentration of androgens was below the limit of detection of this technique $\left(120 \mathrm{pg} / \mathrm{ml}, 0.4 \times 10^{-9} \mathrm{M}\right)$.

To minimize error due to individual variations, tissues from the same animal were used in every instance involving comparison of binding activity of spermatozoa derived from tubules cultured under different conditions. Data were analysed for statistical significance with the $\chi^{2}$ test (distribution of oocytes with different numbers of bound spermatozoa) or the Mann-Whitney test (number of spermatozoa/egg). 


\section{Results}

\section{Effects of cycloheximide}

The ability of spermatozoa from proximal corpus tubules cultured under control conditions was compared with that of spermatozoa from tubules cultured in the presence of $2 \mu \mathrm{M}-5 \alpha-\mathrm{DHT}$, alone or with $20 \mu \mathrm{M}$-cycloheximide. The presence of $5 \alpha$-DHT in the culture medium resulted in a marked increase in zona pellucida binding ability of spermatozoa (Table 2), as reflected by the decrease in the number of oocytes without any bound spermatozoa and the increase in oocytes with larger numbers of bound spermatozoa. The stimulatory effect of androgens was severely reduced to control values when cycloheximide was also added to the culture medium.

Table 2. Effect of addition of androgen $(2 \mu \mathrm{M}-5 \alpha-\mathrm{DHT})$ and cycloheximide (20 $\mu \mathrm{M})$ to the medium on the oocyte binding ability of hamster spermatozoa contained in cultured tubules from the proximal corpus epididymidis

\begin{tabular}{|c|c|c|c|c|c|c|}
\hline \multirow[b]{2}{*}{ Treatment } & \multirow[b]{2}{*}{$\begin{array}{l}\text { No. of } \\
\text { oocytes }\end{array}$} & \multicolumn{4}{|c|}{ No. $(\%)$ of oocytes with } & \multirow{2}{*}{$\begin{array}{c}\text { Mean no. of } \\
\text { spermatozoa/egg } \\
\text { (median) }\end{array}$} \\
\hline & & $\begin{array}{c}0 \\
\text { spermatozoa }\end{array}$ & $\begin{array}{c}1-5 \\
\text { spermatozoa }\end{array}$ & $\begin{array}{c}5-10 \\
\text { spermatozoa }\end{array}$ & $\begin{array}{c}>10 \\
\text { spermatozoa }\end{array}$ & \\
\hline Control & 78 & $* * * 56(72)$ & $18(23)$ & $* * 4(5)$ & $* * 0(0)$ & $\begin{array}{l}0 \cdot 87 \pm 0 \cdot 41 \\
*(0 \cdot 31)\end{array}$ \\
\hline $5 \alpha-\mathrm{DHT}$ & 86 & $35(41)$ & $24(28)$ & $17(20)$ & $10(11)$ & $\begin{array}{c}4 \cdot 29 \pm 1 \cdot 43 \\
(3 \cdot 27)\end{array}$ \\
\hline $\begin{array}{l}5 \alpha-\mathrm{DHT}+ \\
\text { cycloheximide }\end{array}$ & 97 & ${ }^{* *} 64(66)$ & $30(31)$ & ${ }^{* *} 3(3)$ & ${ }^{* *} 0(0)$ & $\begin{array}{l}0.72 \pm 0 \cdot 35 \\
\quad *(0 \cdot 34)\end{array}$ \\
\hline
\end{tabular}

Results are the mean of 11 independent observations.

Compared with values for $5 \alpha-\mathrm{DHT}$ treatment: ${ }^{*} P<0.05,{ }^{* *} P<0.01,{ }^{* * *} P<0.001$.

Table 3. Effect of the addition of a preparation enriched in epididymal glycoproteins (from intact or castrated animals) to the medium upon the oocyte binding ability of hamster spermatozoa contained in cultured tubules from the proximal corpus epididymidis

\begin{tabular}{|c|c|c|c|c|c|c|c|}
\hline \multirow{2}{*}{\multicolumn{2}{|c|}{ Treatment }} & \multirow[b]{2}{*}{$\begin{array}{l}\text { No. of } \\
\text { oocytes }\end{array}$} & \multicolumn{4}{|c|}{ No. $(\%)$ of oocytes with } & \multirow{2}{*}{$\begin{array}{c}\text { Mean no. of } \\
\text { spermatozoa/egg } \\
\text { (median) }\end{array}$} \\
\hline & & & $\begin{array}{c}0 \\
\text { spermatozoa }\end{array}$ & $\begin{array}{c}1-5 \\
\text { spermatozoa }\end{array}$ & $\begin{array}{c}5-10 \\
\text { spermatozoa }\end{array}$ & $\begin{array}{c}>10 \\
\text { spermatozoa }\end{array}$ & \\
\hline \multirow[t]{2}{*}{ (a) } & Control & 124 & $95(77)$ & $28(22)$ & $1(1)$ & $0(0)$ & $0.55 \pm 0 \cdot 19$ \\
\hline & $\begin{array}{l}\text { Protein from } \\
\text { intact animals }\end{array}$ & 132 & $+76(57)$ & $42(32)$ & $4(3)$ & $\dagger 10(8)$ & $\begin{array}{c}2.73 \pm 1.42 \\
\ddagger(0 \cdot 86)\end{array}$ \\
\hline \multirow[t]{2}{*}{ (b) } & $\begin{array}{l}\text { Protein from } \\
\text { intact animals }\end{array}$ & 57 & $27(47)$ & $22(39)$ & $2(3)$ & $6(11)$ & $\frac{2.67 \pm 1.49}{(0.75)}$ \\
\hline & $\begin{array}{l}\text { Protein from } \\
\text { castrated animals }\end{array}$ & 53 & *44 (83) & $* * 5(9)$ & $2(4)$ & $2(4)$ & $\begin{array}{c}1.04 \pm 0.68 \\
* * *(0 \cdot 12)\end{array}$ \\
\hline
\end{tabular}

Results are the mean of (a) 17 and (b) 10 independent observations.

(a) With respect to control values: $\uparrow P<0.01, \ddagger P<0.02$; (b) with respect to values with protein from intact animals: ${ }^{*} P<0.001,{ }^{* *} P<0.01,{ }^{* * *} P<0.05$. 


\section{Effects of epididymal glycoproteins}

Cultures of proximal corpus tubules were exposed for $24 \mathrm{~h}$ to a preparation enriched in epididymal glycoproteins at a final concentration of $1 \mathrm{mg}$ protein $/ \mathrm{ml}$. There was a significant increase in the zona pellucida binding ability of these spermatozoa with respect to controls (Table 3a). The effect of the preparation enriched in epididymal glycoproteins was lost when the corresponding fraction was prepared with epididymal cytosol obtained from animals castrated for 30 days (Table $3 b$ ).

\section{Discussion}

In view of the synchronous development of zona binding and fertilizing ability during epididymal passage (Saling, 1982; Fournier-Delpech et al., 1982), the results of Cuasnicú et al. (1984) were interpreted as an indication that androgens added to the medium could promote the maturation of spermatozoa contained in cultured tubules. The present results, using cycloheximide as inhibitor of protein synthesis, demonstrated that the effect of $5 \alpha$-DHT on sperm-zona pellucida binding ability was blocked, suggesting that de-novo synthesis of proteins is required to obtain the response. Use of an androgen-depleted fraction enriched in glycoproteins EP2-EP6 led to an increased zona binding ability. The possibility that androgens contaminating our protein preparation may be responsible for the effect obtained can be ruled out since the concentration of active hormone $(<0.4 \mathrm{nM})$ is several orders of magnitude below the minimum level required $(2 \mu \mathrm{M})$ to obtain an effect on zona binding ability (Cuasnicú et al., 1984). Likewise, the bulk of lipid constituents of the cytosol were presumably removed by the purification procedures used to obtain the fraction enriched in epididymal proteins.

Although these results support the proposed role for the proteins, further studies are required to demonstrate the association of exogenously added protein to spermatozoa and to determine unequivocally that these are the active factors in the epididymal preparation. When a protein preparation obtained from castrated animals was used, the effect of epididymal proteins was lost. This is in agreement not only with the previously demonstrated hormonal control of maturation (Blaquier, Cameo \& Burgos, 1972; Orgebin-Crist, Danzo \& Davies, 1975) but also with the decrease in the amounts of proteins EP1-EP6 in hamster epididymis after castration (González Echeverria et al., 1982). A hamster sperm membrane protein, of $M_{r} 24000$, has been reported to be the preferential binder of solubilized zona pellucida proteins (Sullivan, St Jacques, Chapdelaine, Roberts \& Bleau, 1983). This is also the molecular weight of EP3 (González Echeverria et al., 1982) which is one of the proteins we believe to be involved in the process of formation or activation of the receptor for zona pellucida on the surface of spermatozoa. An indication of the possible mechanism of interaction between epididymal proteins and spermatozoa was provided by the identification of high-affinity binding sites for a rat 32000 epididymal protein on the sperm plasma membrane (Wong \& Tsang, 1982).

Our results confirm data obtained with rabbit epididymides in culture in which androgens support the continuation of the maturation process (Orgebin-Crist \& Tichenor, 1973) by a mechanism apparently involving newly synthesized epididymal proteins (Orgebin-Crist \& Jahad, 1978 , 1979). Prior exposure of rat testicular spermatozoa to a purified androgen-dependent epididymal glycoprotein increases their ability to interact with the zona pellucida (Orgebin-Crist \& Fournier-Delpech, 1982).

\section{References}

Blaquier, J.A., Cameo, M.S. \& Burgos, M.H. (1972) The role of androgens in the maturation of epididymal spermatozoa in the guinea pig. Endocrinology 90, 839-842.

Brinster, R.L. (1965) Studies on the development of mouse embryos in vitro. IV. Interaction of energy sources. J. Reprod. Fert. 10, 227-240.

Cuasnicú, P.S., González Echeverría, F., Piazza, A. \& Blaquier, J.A. (1984) Addition of androgens to cultured hamster epididymis increases zona recogni- 
tion by immature spermatozoa. J. Reprod. Fert. $\mathbf{7 0}$, 541-547.

Fournier-Delpech, S., Courtens, J.L., Pisselet, C.L., Delaleu, B. \& Courot, M. (1982) Acquisition of zona binding by ram spermatozoa during epididymal passage, as revealed by interaction with rat oocytes. Gamete Res. 4, 403-408.

Garberi, J.C., Kohane, A.C., Cameo, M.S. \& Blaquier, J.A. (1979) Isolation and characterization of specific rat epididymal proteins. Molec. cell. Endocr. 13, 73 82.

González Echeverría, F.M., Cuasnicú, P.S. \& Blaquier, J.A. (1982) Identification of androgen-dependent glycoproteins in the hamster epididymis and their association with spermatozoa. J. Reprod. Fert. 64, 17.

Horan, A.H. \& Bedford, J.M. (1972) Development of the fertilizing ability of spermatozoa in the epididymis of the Syrian hamster. J. Reprod. Fert. 30, 417-423.

Orgebin-Crist, M.C. \& Fournier-Delpech, S. (1982) Sperm-egg interaction. Evidence for maturational changes during epididymal transit. $J$. Androl. 3, 429433.

Orgebin-Crist, M.C. \& Jahad, N. (1978) The maturation of spermatozoa in organ culture: inhibition of antiandrogens and inhibitors of ribonucleic acid and protein synthesis. Endocrinology 103, 46-53.
Orgebin-Crist, M.C. \& Jahad, N. (1979) The maturation of rabbit epididymal spermatozoa in organ culture: stimulation by epididymal cytoplasmic extracts. Biol. Reprod. 21, 511-516.

Orgebin-Crist, M.C. \& Tichenor, P. (1973) Effect of testosterone on sperm maturation in vitro. Nature, Lond. 245, 328-329.

Orgebin-Crist, M.C., Danzo, B.J. \& Davies, J. (1975) Endocrine control of the development and maintenance of sperm fertilizing ability in the epididymis. In Handbook of Physiology, Section 7, vol. 5, pp. 319333. Eds D. W. Hamilton \& R. O. Greep. American Physiological Society, Washington D.C.

Saling, P.M. (1982) Development of the ability to bind to zonae pellucidae during epididymal maturation: reversible immobilization of mouse spermatozoa by lanthanum. Biol. Reprod. 26, 429 436.

Sullivan, R., St Jacques, S., Chapdelaine, A., Roberts, K.D. \& Bleau, G. (1983) Detection of a sperm membrane protein with an affinity for the zona pellucida. Biol. Reprod. 28, Suppl. 1, 39, Abstr. 13.

Wong, P.Y.D. \& Tsang, A.Y.F. (1982) Studies on the binding of a $32 \mathrm{~K}$ rat epididymal protein to rat epididymal spermatozoa. Biol. Reprod. 27, 1239-1246.

Received 11 October 1983 